\title{
Communication \\ The Coxsackievirus and Adenovirus Receptor Has a Short Half-Life in Epithelial Cells
}

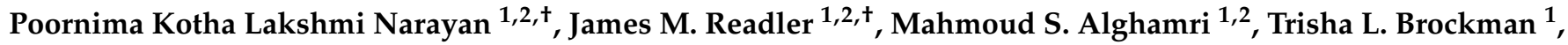 \\ Ran Yan ${ }^{1}$, Priyanka Sharma ${ }^{1}$, Vladislav Snitsarev ${ }^{3}$, Katherine J. D. A. Excoffon ${ }^{1,2}$ and \\ Abimbola O. Kolawole ${ }^{1,2, *(1)}$ \\ 1 Department of Biological Sciences, Wright State University, Dayton, OH 45435, USA; \\ poornimakotha@gmail.com (P.K.L.N.); readler.3@wright.edu (J.M.R.); alghamma@med.umich.edu (M.S.A.); \\ trisha.brockman.20@gmail.com (T.L.B.); renaranyan@gmail.com (R.Y.); priyankasharma18@gmail.com (P.S.); \\ katherine.excoffon@wright.edu (K.J.D.A.E.) \\ 2 Biomedical Sciences PhD Program, Wright State University, Dayton, OH 45435, USA \\ 3 Biology Department, Montclair State University, Montclair, NJ 07043, USA; Snitsarevv@mail.montclair.edu \\ * Correspondence: ola.kolawole@wright.edu; Tel.: +1-9377752301; Fax: +1-9377753320 \\ + These authors contributed equally to this work.
}

Citation: Kotha Lakshmi Narayan, P.; Readler, J.M.; Alghamri, M.S.;

Brockman, T.L.; Yan, R.; Sharma, P.; Snitsarev, V.; Excoffon, K.J.D.A.; Kolawole, A.O. The Coxsackievirus and Adenovirus Receptor Has a Short Half-Life in Epithelial Cells.

Pathogens 2022, 11, 173.

https://doi.org/10.3390/

pathogens 11020173

Academic Editor:

Lawrence S. Young

Received: 13 December 2021

Accepted: 24 January 2022

Published: 27 January 2022

Publisher's Note: MDPI stays neutral with regard to jurisdictional claims in published maps and institutional affiliations.

Copyright: (C) 2022 by the authors. Licensee MDPI, Basel, Switzerland. This article is an open access article distributed under the terms and conditions of the Creative Commons Attribution (CC BY) license (https:// creativecommons.org/licenses/by/ $4.0 /)$.

\begin{abstract}
The coxsackievirus and adenovirus receptor (CAR) is an essential cellular protein that is involved in cell adhesion, cell signaling, and viral infection. The 8-exon encoded isoform $\left(\mathrm{CAR}^{\mathrm{Ex} 8}\right)$ resides at the apical surface of polarized epithelia, where it is accessible as a receptor for adenovirus entering the airway lumen. Given its pivotal role in viral infection, it is a target for antiviral strategies. To understand the regulation of $\mathrm{CAR}^{\mathrm{Ex} 8}$ and determine the feasibility of receptor downregulation, the half-life of total and apical localized $\mathrm{CAR}^{\mathrm{Ex} 8}$ was determined and correlated with adenovirus transduction. Total and apical $C A R^{E x 8}$ has a relatively short half-life of approximately $2 \mathrm{~h}$. The halflife of apical $\mathrm{CAR}^{\mathrm{Ex} 8}$ correlates well with adenovirus transduction. These results suggest that antiviral strategies that aim to degrade the primary receptor for apical adenovirus infection will be effective within a relatively short time frame after application.
\end{abstract}

Keywords: human adenovirus; coxsackievirus and adenovirus receptor; half-life; polarized epithelia

Acute respiratory tract infections are a major cause of morbidity and mortality worldwide, especially among children and elderly populations. In particular, respiratory viruses are one of the major contributors of acute respiratory tract infections [1,2]. Human adenoviruses $(\mathrm{HAdV})$ mediate respiratory infections that are usually self-limiting in healthy individuals. However, these viruses can occasionally cause fatal illness in both adults and children, especially in immunosuppressed populations [3]. Novel approaches to inhibit HAdV infection in both healthy and susceptible populations are likely to reduce the morbidity and mortality associated with HAdV pathogenesis. HAdV are classified into seven species (HAdV-A through -G) and include more than 100 genotypes (http:/ / hadvwg.gmu.edu/122021) [4]. Like all viruses, the first step for successful HAdV infection is attachment to the host cell. All species, except HAdV-B, can use the coxsackievirus and adenovirus receptor (CAR) as the primary receptor for attachment [5-7]. Two transmembrane isoforms of CAR are present in polarized epithelial cells: an isoform encoded by the first seven exons $\left(\mathrm{CAR}^{\mathrm{Ex} 7}\right)$ of the CXADR gene and an isoform that is alternatively spliced from a cryptic splice site within the seventh exon to the eighth exon $\left(\mathrm{CAR}^{\mathrm{Ex} 8}\right)[8,9]$. As a result of this differential splicing event, $\mathrm{CAR}^{\mathrm{Ex} 7}$ and $\mathrm{CAR}^{\mathrm{Ex} 8}$ differ only in the amino acid sequence at the extreme C-terminus. This difference is responsible for the differential localization of the two CAR isoforms within polarized epithelial cells. CAR ${ }^{\text {Ex7 }}$, the more abundant isoform, localizes at the basolateral surface of polarized epithelial cells, while $\mathrm{CAR}^{\mathrm{Ex} 8}$ localizes at the apical surface. Our lab has previously shown that $\mathrm{CAR}^{\mathrm{Ex} 8}$ 
mediates apical adenoviral infection in polarized epithelial cells and that the susceptibility to adenovirus infection correlates with the level of $\mathrm{CAR}^{\mathrm{Ex} 8}$ expression [8,10-14]. Moreover, $\mathrm{HAdV}$ appears to have co-opted an innate immune response that stimulates the expression and the localization of $\mathrm{CAR}^{\mathrm{Ex} 8}$ at the apical surface of polarized epithelial cells in order to more efficiently gain entry and initiate infection [13].

CAR has many important physiologic functions, including: homophilic and heterophilic cellular adhesion, immune activation, and cardiac conduction [15-21]. CAR knockout is embryonically lethal as it is crucial for normal development of the heart and lymphatic system [21-24]. CAR expression is shown to correlate with some types of epithelial cell-derived cancer, such as lung, breast, ovary, and cervical cancers [18,25-30]. In polarized epithelial cells, $\mathrm{CAR}^{\mathrm{Ex} 7}$ forms homodimers on the basolateral surface with those on the adjacent cells and is essential for maintaining the epithelial cell junctions and barrier integrity [31-34]. We also discovered a novel function for $C A R^{\mathrm{Ex} 8}$, which is to facilitate the innate immune response by serving as an adhesion protein for infiltrating neutrophils at the apical surface of polarized epithelial cells [13]. Given the physiologic importance of $\mathrm{CAR}^{\mathrm{Ex} 8}$, it is logical to assume that regulatory mechanisms tightly control its expression. Therefore, the goal of these studies was to determine the half-life of $C A R^{\mathrm{Ex} 8}$ and correlate the expression levels at the apical surface with adenovirus infection for a better understanding of $\mathrm{CAR}^{\mathrm{Ex} 8}$ regulation.

The generation of MDCK cell lines stably carrying a doxycycline (Dox)-inducible expression cassette for FLAG-tagged human $\mathrm{CAR}^{\mathrm{Ex} 8}$ has previously been described in detail [13]. In order to determine the half-life of $\mathrm{CAR}^{\mathrm{Ex} 8}$ in the inducible epithelial cells, we first asked how long it takes to detect $C A R^{\mathrm{Ex} 8}$ expression after exposure to Dox. To address this question, MDCK-CAR ${ }^{\mathrm{Ex} 8}$ stable cells were seeded in a plastic 12-well dish in FBS tet $^{(-)}$media. The cells were induced with $100 \mathrm{ng} / \mathrm{mL}$ Dox for $24 \mathrm{~h}$, and then harvested at the indicated time points. Cell lysates were analyzed for FLAG-tagged CAR ${ }^{\mathrm{Ex} 8}$ protein expression via Western blot (WB) as previously described [10]. CAR ${ }^{\mathrm{Ex} 8}$ could be detected as early as $4 \mathrm{~h}$ after induction with Dox and increased over time (Figure 1A). The removal of Dox causes the translation of FLAG-tagged human $\mathrm{CAR}^{\mathrm{Ex} 8}$ to cease, allowing for the measurement of $\mathrm{CAR}^{\mathrm{Ex} 8}$ turnover. The results show that the induced $\mathrm{CAR}^{\mathrm{Ex} 8}$ protein degraded over time and was undetectable after $24 \mathrm{~h}$. Next, using a pulse chase experimental design, we again monitored $\mathrm{CAR}^{\mathrm{Ex} 8}$ protein degradation over time. MDCK-CAR ${ }^{\mathrm{Ex} 8}$-stable cells were seeded in a plastic 12-well dish in FBS tet ${ }^{(-)}$media and $\mathrm{CAR}^{\mathrm{Ex} 8}$ expression was induced with $100 \mathrm{ng} / \mathrm{mL}$ Dox. At $24 \mathrm{~h}$ post induction, Dox was removed and the cells were harvested at the indicated time points and analyzed by WB. CAR ${ }^{\mathrm{Ex} 8}$ expression was stable for approximately $8 \mathrm{~h}$ after Dox removal, after which the protein level decreased rapidly, by half at $10 \mathrm{~h}$. CAR ${ }^{\mathrm{Ex} 8}$ decreased again by another half from $10 \mathrm{~h}$ to $12 \mathrm{~h}$ and was undetectable at $24 \mathrm{~h}$ (Figure 1B). The WB bands were quantified and normalized to actin using ImageJ in order to calculate the half-life of $C A R^{\mathrm{Ex} 8}$. The half-life of $C A R^{\mathrm{Ex} 8}$ was determined to be $2.0 \pm 1.4 \mathrm{~h}$ (Figure $1 \mathrm{C}$ ). As the primary adenovirus receptor, the presence of $\mathrm{CAR}^{\mathrm{Ex} 8}$ at the apical surface, where it is accessible to incoming virions, is arguably the major factor that defines the susceptibility of the epithelium to viral infection. To determine the rate of $\mathrm{CAR}^{\mathrm{Ex} 8}$ turnover at the apical surface, we induced polarized MDCK-CAR ${ }^{\mathrm{Ex} 8}$ epithelia with media containing $100 \mathrm{ng} / \mathrm{mL}$ Dox for $24 \mathrm{~h}$, as previously described [13]. After $24 \mathrm{~h}$ of induction, Dox was removed and replaced with fresh tet ${ }^{(-)}$medium for $0,4,8$, 12 and $24 \mathrm{~h}$. The treatment with Dox and removal of Dox was staggered so that surface biotinylation for all conditions could be performed at the same time. Once each time point was met, apical surface biotinylation was performed as described [35], and the biotinylated proteins were isolated with streptavidin beads and analyzed via WB. The CAR ${ }^{\mathrm{Ex} 8}$ protein appears to be relatively stable for the initial $4 \mathrm{~h}$ after Dox removal but then decrease to undetectable levels by $24 \mathrm{~h}$. By $8 \mathrm{~h}$ post Dox removal, the $\mathrm{CAR}^{\mathrm{Ex} 8}$ protein appears to have decreased to nearly $25 \%$ of its original amount (Figure 1D). A quantification of the $C A R^{E x 8}$ protein bands revealed that the half-life of apical $C A R^{\mathrm{Ex} 8}$ is like that of a total $C A R^{\mathrm{Ex} 8}$ at $1.8 \pm 1.9 \mathrm{~h}$ (Figure 1E). 

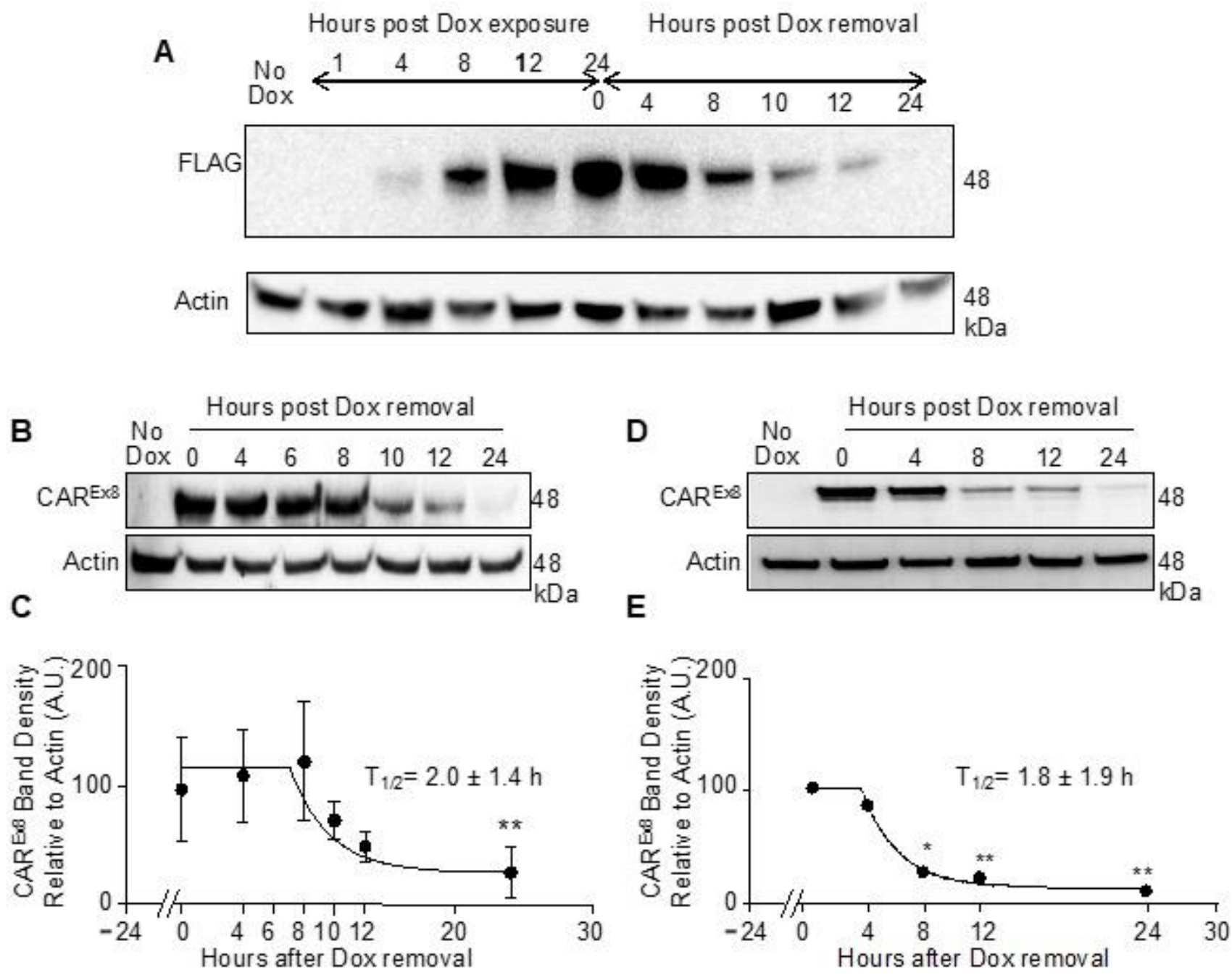

Figure 1. $C A R^{\mathrm{Ex} 8}$ has a half-life of approximately $2 \mathrm{~h}$. MDCK cells that stably expressed FLAG-tagged $\mathrm{CAR}^{\mathrm{Ex} 8}$ under the control of a doxycycline-sensitive promoter were seeded in a plastic 12-well dish in FBS tet ${ }^{(-)}$media. Cells were induced with $100 \mathrm{ng} / \mathrm{mL}$ doxycycline for $24 \mathrm{~h}$. The doxycycline-

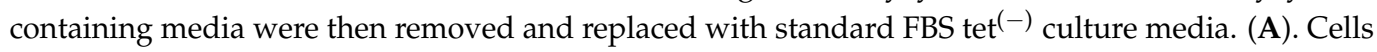
were lysed at indicated time points before and after removal of Dox and the lysates were analyzed by Western blot (WB) using anti-FLAG or actin-specific primary antibodies. (B). Cells were lysed at indicated time points post Dox removal and lysates were analyzed by WB. (C). CAR ${ }^{\mathrm{Ex} 8}$ bands were normalized to their corresponding actin bands and quantified using ImageJ. (D). MDCK-FLAG$\mathrm{CAR}^{\mathrm{Ex} 8}$ were polarized on semipermeable membranes. At $24 \mathrm{~h}$ post Dox treatment, standard FBS tet $^{(-)}$culture media were added and surface biotinylation was performed at indicated time points post Dox removal. Cells were then lysed and the lysates (actin) or isolated-biotinylated proteins (CAR ${ }^{\mathrm{Ex} 8}$, FLAG $\mathrm{Ab}$ ) were analyzed via WB. (E). CAR ${ }^{\mathrm{Ex} 8}$ bands were normalized to their corresponding actin bands and quantified using ImageJ. Error bars represent SEM. $\left({ }^{*} p<0.05 ;{ }^{* *} p<0.01\right.$; One-Way ANOVA; $\mathrm{N}$ at least 3).

We conducted these studies in the MDCK epithelial cell line because of its extensive use in studies related to cell polarity $[13,35,36]$. These cells form well-defined junctions, are easy to cultivate, and are suitable for both 2D and 3D cultures [37]. However, the CAR ${ }^{\text {Ex8 }}$ half-life in an inducible MDCK stable cell line may present several limitations: (i) Lung and kidney epithelial cells may degrade proteins using different mechanisms or at different rates; (ii) The gene that encodes FLAG-tagged CAR ${ }^{E x 8}$ within the integrated inducible vector is human [38]. Thus, the species difference may result in differential recognition or degradation for endogenous CAR; (iii) Overexpression of this protein may overwhelm the 
cell's regulatory machinery; (iv) Residual mRNA from overexpression or Dox remaining within the cell may allow for continued protein translation despite the removal of Dox from the media, possibly altering the time frame of degradation; and (v) The FLAG-tag on the protein may disturb or alter the rate of protein degradation. To address these limitations and confirm that the MDCK-CAR ${ }^{\mathrm{Ex} 8}$-stable cell line was an appropriate model system, the half-life of endogenous $C_{A R}{ }^{E x 8}$ was also determined in the Calu-3 cell line, a wellstudied human lung adenocarcinoma cell line able to polarize into an epithelium. This was accomplished by inhibiting protein synthesis in Calu-3 cells with $30 \mu \mathrm{g} / \mathrm{mL}$ cycloheximide treatment for increasing periods of time prior to epithelial cell lysis. The epithelia were then lysed and the total cellular levels of $C A R^{E x 8}$ were measured by WB using $C A R^{E x}{ }^{\text {-specific }}$ $\mathrm{Ab}$ (5678p, University of Iowa), relative to actin (Figure 2A). The half-life of $2.4 \mathrm{~h} \pm 0.05 \mathrm{~h}$ obtained for endogenous $\mathrm{CAR}^{\mathrm{Ex} 8}$ in Calu-3 cells was similar to the half-life found for $\mathrm{CAR}^{\mathrm{Ex} 8}$ in the MDCK-stable cell lines (Figure 2B).

A

Hours post $\mathrm{CHX}$ treatment

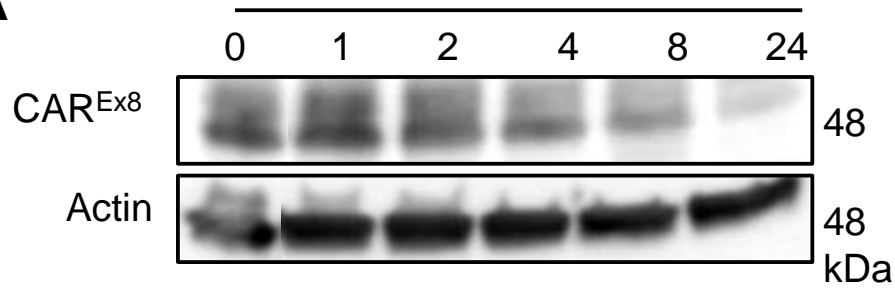

B

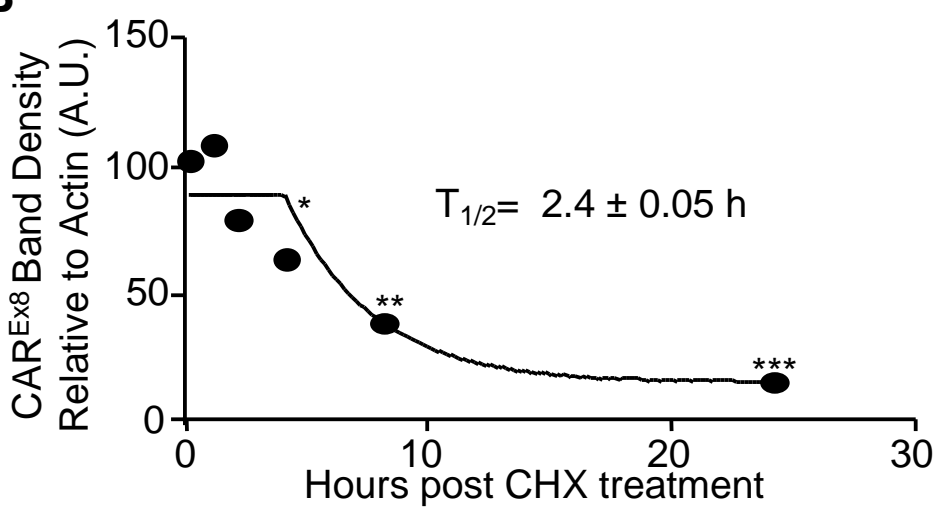

Figure 2. $C A R^{E x 8}$ has a half-life of approximately 2 h. (A) Calu-3 cells were treated with $30 \mu \mathrm{g} / \mathrm{mL}$ cycloheximide. The cells were lysed at the times indicated post cycloheximide addition and analyzed by WB using a CAR ${ }^{\mathrm{Ex} 8}$-specific primary antibody (5678p) or actin (loading control). (B) Quantification of $\mathrm{CAR}^{\mathrm{Ex} 8}$ bands normalized to actin. Error bars represent SEM. $\left({ }^{*} p<0.05 ;{ }^{* *} p<0.01 ;{ }^{* *} p<0.001\right.$; One-Way ANOVA; $\mathrm{N}$ at least 3).

The induction of MDCK CAR ${ }^{\mathrm{Ex} 8}$-stable cells with Dox increased the expression of $\mathrm{CAR}^{\mathrm{Ex} 8}$ (Figure 1) and correspondingly increased the adenovirus infection of polarized epithelial cells [13]. The removal of Dox reverted the cells back to a state in which no FLAG-tagged CAR ${ }^{\mathrm{Ex} 8}$ could be detected (Figure 1), and background levels of CAR ${ }^{\mathrm{Ex} 8}$ were very low $[13,39]$. Thus, we hypothesized that the susceptibility of the MDCK epithelium to apical HAdV5 transduction would decrease at the same rate as $\mathrm{CAR}^{\mathrm{Ex} 8}$ degradation. To test this, polarized MDCK CAR ${ }^{\mathrm{Ex} 8}$-stable cells were induced with $100 \mathrm{ng} / \mathrm{mL}$ Dox for $24 \mathrm{~h}$. After $24 \mathrm{~h}$ of induction, Dox was removed and replaced with fresh tet ${ }^{(-)}$medium for $0,4,6$, $8,10,12$ and $24 \mathrm{~h}$. The treatment with Dox and removal of Dox were staggered so that the $\beta$-galactosidase assay for all conditions could be performed at the same time. Once each time point was met, the apical surfaces of epithelia were inoculated with a recombinant adenovirus carrying the $\beta$-galactosidase reporter gene (HAdV5- $\beta$-Gal; MOI 100 , University of Iowa Vector Core, Iowa City, IA, USA) for $1 \mathrm{~h}$, as previously described [13]. The apical surface was then washed, and $\beta$-galactosidase activity was analyzed $24 \mathrm{~h}$ later to determine 
AdV transduction as described [35]. The results show a significant decrease in AdV5 transduction (Figure 3 ) that corresponds well with the decrease in $\mathrm{CAR}^{\mathrm{Ex} 8}$ protein levels (Figure 1). These results indicate that $\mathrm{CAR}^{\mathrm{Ex} 8}$ localized at the apical surface of polarized epithelia acts as the primary receptor for adenoviruses. Our data also confirm that the presence of apical CAR ${ }^{\mathrm{Ex} 8}$ is one of the primary factors determining the susceptibility of a polarized epithelium to HAdV infection [13].

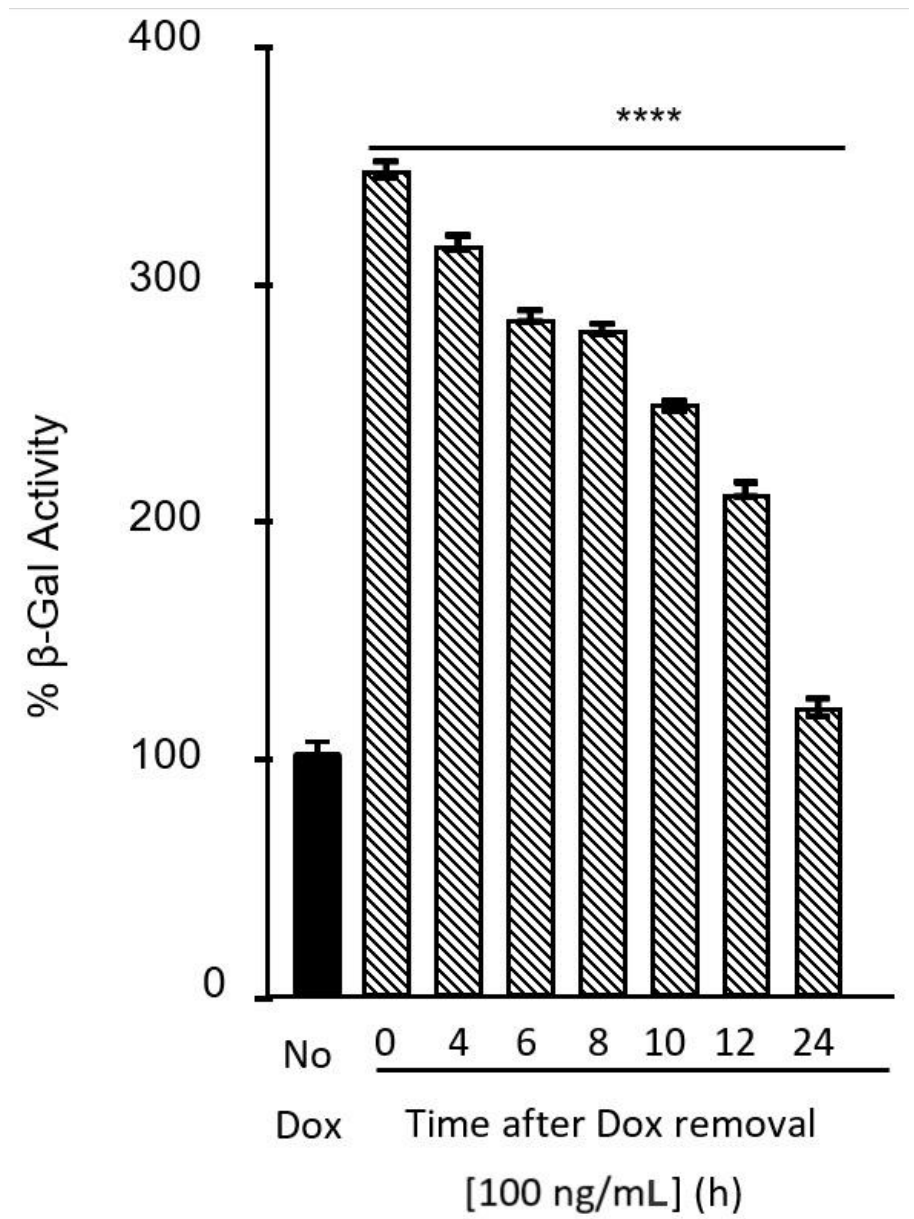

Figure 3. Adenovirus transduction decreases as $C A R^{\mathrm{Ex} 8}$ degrades. MDCK-FLAG-CAR ${ }^{\mathrm{Ex} 8}$ were seeded and polarized in FBS tet ${ }^{(-)}$media. The cells were then treated with $100 \mathrm{ng} / \mathrm{mL}$ Dox for $24 \mathrm{~h}$. At $24 \mathrm{~h}$ post treatment, the doxycycline-containing media were removed and replaced with standard FBS tet ${ }^{(-)}$culture media. At 4, 6, 8, 10, 12, and $24 \mathrm{~h}$ post dox removal, cells were transduced with AdV- $\beta$-Gal. AdV transduction was analyzed by $\beta$-galactosidase assay after $24 \mathrm{~h}$. Error bars indicate standard error of the mean. ${ }^{* * * *} p<0.0001$; One-Way ANOVA; $\mathrm{N}=3$ ).

Overall, this work highlights the potential importance of targeting CAR ${ }^{\mathrm{Ex} 8}$ as a means of preventing HAdV infection [14]. Protein turnover plays an important role in all cellular processes. Therefore, knowing the rate at which a protein is degraded can have significant implications for the advancement of directed therapeutics in treating many diseases. In instances where there are several different isoforms of a protein, with the differential localization of each separate isoform, and a varied amount of each isoform under standard cellular conditions, knowing the half-life of each isoform could provide an insight into protein function and regulation. Protein degradation is usually a first-order reaction; thus, the half-lives of $\mathrm{CAR}^{\mathrm{Ex} 8}$ in different cell lines were analyzed using a plateau followed by a one-phase exponential decay $[40,41]$. Protein half-lives differ from protein to protein.

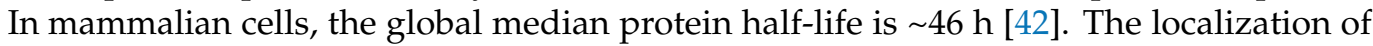
a protein within a polarized epithelium may play a significant role in a protein's half-life. 
Apical proteins have been shown to have half-lives ranging from $\sim 1 \mathrm{~h}$ to $\sim 24 \mathrm{~h}$ and global analysis conferred that plasma membrane proteins can have half-lives of $100 \mathrm{~h}$ or shorter

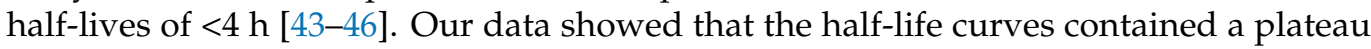
followed by a one-phase decay. The plateau principle is applied to biological systems when a drug is being administered continuously or at steady intervals, which can affect cellular functions. It also applies to endogenous cases, such as protein abundance in response to a hormone. In our case, our cells were exposed to a continuous amount of Dox for a $24 \mathrm{~h}$ time frame. Dox induced the expression of mRNA transcripts. Once the Dox was removed, we hypothesized that the plateau effect was caused by residual mRNA being translated after Dox removal. Additionally, $\mathrm{CAR}^{\mathrm{Ex} 8}$ was shown to be negatively regulated by the scaffolding protein MAGI-1 [10,47]. This could account for decreased protein stability, and thus a relatively short half-life. The short half-life of $\mathrm{CAR}^{\mathrm{Ex} 8}$ may also be a consequence of the protein's native physiological role in neutrophil transmigration, a process that only requires $\mathrm{CAR}^{\mathrm{Ex} 8}$ to be expressed in short, transient bursts.

In summary, our findings demonstrate that apical $C A R^{\mathrm{E} x}$ has a half-life of approximately $2 \mathrm{~h}$ and that the residence of $\mathrm{CAR}^{\mathrm{Ex} 8}$ at the apical surface is a major factor in determining the susceptibility of an epithelium to HAdV infection. These data suggest that novel methods to enhance the downregulation of the primary apical adenovirus receptor, such as targeting MAGI-1, would work in a reasonably short time frame and, similarly, be reversible in a relatively short time frame [14]. This may lead to a novel class of antivirals that decrease the apical viral infection of epithelia.

Author Contributions: Conceptualization, P.K.L.N., J.M.R., M.S.A., T.L.B., R.Y., P.S., V.S., K.J.D.A.E. and A.O.K.; methodology, P.K.L.N., J.M.R., M.S.A., T.L.B., R.Y. and P.S.; supervision, V.S., K.J.D.A.E. and A.O.K.; funding acquisition, K.J.D.A.E. and A.O.K.; writing, P.K.L.N., J.M.R., K.J.D.A.E. and A.O.K. All authors have read and agreed to the published version of the manuscript.

Funding: This work was funded by the National Institute of Allergy and Infectious Diseases of the National Institutes of Health under award number R01AI127816.

Conflicts of Interest: The authors declare no conflict of interest. The funders had no role in the design of the study; in the collection, analyses, or interpretation of data; in the writing of the manuscript, or in the decision to publish the results.

\section{References}

1. Tregoning, J.S.; Schwarze, J. Respiratory viral infections in infants: Causes, clinical symptoms, virology, and immunology. Clin. Microbiol. Rev. 2010, 23, 74-98. [CrossRef] [PubMed]

2. Vareille, M.; Kieninger, E.; Edwards, M.R.; Regamey, N. The airway epithelium: Soldier in the fight against respiratory viruses. Clin. Microbiol. Rev. 2011, 24, 210-229. [CrossRef] [PubMed]

3. William, S.M.; Wold, M.S.H. Adenoviruses. In Fields Virology; David, M., Knipe, P.M.H., Eds.; Lippincott Williams and Wilkins: Philadelphia, PA, USA, 2007; Volume 2, pp. 2395-2436.

4. Robinson, C.M.; Singh, G.; Lee, J.Y.; Dehghan, S.; Rajaiya, J.; Liu, E.B.; Yousuf, M.A.; Betensky, R.A.; Jones, M.S.; Dyer, D.W.; et al. Molecular evolution of human adenoviruses. Sci. Rep. 2013, 3, 1812. [CrossRef] [PubMed]

5. Arnberg, N. Adenovirus receptors: Implications for targeting of viral vectors. Trends Pharmacol. Sci. 2012, 33, 442-448. [CrossRef] [PubMed]

6. Berk, A. Adenoviridae: The Viruses and Their Replication. In Fields Virology, 5th ed.; Howley, D.K.A.P., Ed.; Lippincott Williams and Wilkins: Philadelphia, PA, USA, 2007; Volume 2.

7. Kremer, E.J.; Nemerow, G.R. Adenovirus tales: From the cell surface to the nuclear pore complex. PLoS Pathog. 2015, 11, e1004821. [CrossRef] [PubMed]

8. Excoffon, K.J.; Gansemer, N.D.; Mobily, M.E.; Karp, P.H.; Parekh, K.R.; Zabner, J. Isoform-specific regulation and localization of the coxsackie and adenovirus receptor in human airway epithelia. PLoS ONE 2010, 5, e9909. [CrossRef]

9. Excoffon, K.J.; Bowers, J.R.; Sharma, P. Alternative splicing of viral receptors: A review of the diverse morphologies and physiologies of adenoviral receptors. Recent Res. Dev. Virol. 2014, 9, 1-24.

10. Kolawole, A.O.; Sharma, P.; Yan, R.; Lewis, K.J.; Xu, Z.; Hostetler, H.A.; Ashbourne Excoffon, K.J. The PDZ1 and PDZ3 domains of MAGI-1 regulate the eight-exon isoform of the coxsackievirus and adenovirus receptor. J. Virol. 2012, 86, 9244-9254. [CrossRef]

11. Sharma, P.; Kolawole, A.O.; Core, S.B.; Kajon, A.E.; Excoffon, K.J. Sidestream smoke exposure increases the susceptibility of airway epithelia to adenoviral infection. PLOS ONE 2012, 7, e49930. [CrossRef] 
12. Sharma, P.; Kolawole, A.O.; Wiltshire, S.M.; Frondorf, K.; Excoffon, K.J. Accessibility of the coxsackievirus and adenovirus receptor and its importance in adenovirus gene transduction efficiency. J. Gen. Virol. 2012, 93, 155-158. [CrossRef]

13. Kotha, P.L.; Sharma, P.; Kolawole, A.O.; Yan, R.; Alghamri, M.S.; Brockman, T.L.; Gomez-Cambronero, J.; Excoffon, K.J. Adenovirus entry from the apical surface of polarized epithelia is facilitated by the host innate immune response. PLoS Pathog. 2015, 11, e1004696. [CrossRef] [PubMed]

14. Alghamri, M.S.; Sharma, P.; Williamson, T.L.; Readler, J.M.; Yan, R.; Rider, S.D., Jr.; Hostetler, H.A.; Cool, D.R.; Kolawole, A.O.; Excoffon, K. MAGI-1 PDZ2 Domain Blockade Averts Adenovirus Infection via Enhanced Proteolysis of the Apical Coxsackievirus and Adenovirus Receptor. J. Virol. 2021, 95, e0004621. [CrossRef] [PubMed]

15. Zen, K.; Liu, Y.; McCall, I.C.; Wu, T.; Lee, W.; Babbin, B.A.; Nusrat, A.; Parkos, C.A. Neutrophil migration across tight junctions is mediated by adhesive interactions between epithelial coxsackie and adenovirus receptor and a junctional adhesion molecule-like protein on neutrophils. Mol. Biol. Cell 2005, 16, 2694-2703. [CrossRef] [PubMed]

16. Witherden, D.A.; Verdino, P.; Rieder, S.E.; Garijo, O.; Mills, R.E.; Teyton, L.; Fischer, W.H.; Wilson, I.A.; Havran, W.L. The junctional adhesion molecule JAML is a costimulatory receptor for epithelial gammadelta T cell activation. Science 2010, 329, 1205-1210. [CrossRef] [PubMed]

17. Verdino, P.; Witherden, D.A.; Havran, W.L.; Wilson, I.A. The molecular interaction of CAR and JAML recruits the central cell signal transducer PI3K. Science 2010, 329, 1210-1214. [CrossRef]

18. Ortiz-Zapater, E.; Santis, G.; Parsons, M. CAR: A key regulator of adhesion and inflammation. Int. J. Biochem. Cell Biol. 2017, 89, 1-5. [CrossRef]

19. Walters, R.W.; Freimuth, P.; Moninger, T.O.; Ganske, I.; Zabner, J.; Welsh, M.J. Adenovirus fiber disrupts CAR-mediated intercellular adhesion allowing virus escape. Cell 2002, 110, 789-799. [CrossRef]

20. Kallewaard, N.L.; Zhang, L.; Chen, J.W.; Guttenberg, M.; Sanchez, M.D.; Bergelson, J.M. Tissue-specific deletion of the coxsackievirus and adenovirus receptor protects mice from virus-induced pancreatitis and myocarditis. Cell Host Microbe 2009, 6, 91-98. [CrossRef]

21. Mirza, M.; Pang, M.F.; Zaini, M.A.; Haiko, P.; Tammela, T.; Alitalo, K.; Philipson, L.; Fuxe, J.; Sollerbrant, K. Essential role of the coxsackie- and adenovirus receptor (CAR) in development of the lymphatic system in mice. PLoS ONE 2012, 7, e37523. [CrossRef]

22. Asher, D.R.; Cerny, A.M.; Weiler, S.R.; Horner, J.W.; Keeler, M.L.; Neptune, M.A.; Jones, S.N.; Bronson, R.T.; Depinho, R.A.; Finberg, R.W. Coxsackievirus and adenovirus receptor is essential for cardiomyocyte development. Genesis 2005, 42, 77-85. [CrossRef]

23. Chen, J.W.; Zhou, B.; Yu, Q.C.; Shin, S.J.; Jiao, K.; Schneider, M.D.; Baldwin, H.S.; Bergelson, J.M. Cardiomyocyte-specific deletion of the coxsackievirus and adenovirus receptor results in hyperplasia of the embryonic left ventricle and abnormalities of sinuatrial valves. Circ. Res. 2006, 98, 923-930. [CrossRef]

24. Lim, B.K.; Xiong, D.; Dorner, A.; Youn, T.J.; Yung, A.; Liu, T.I.; Gu, Y.; Dalton, N.D.; Wright, A.T.; Evans, S.M.; et al. Coxsackievirus and adenovirus receptor (CAR) mediates atrioventricular-node function and connexin 45 localization in the murine heart. J. Clin. Investig. 2008, 118, 2758-2770. [CrossRef] [PubMed]

25. Chen, Z.; Wang, Q.; Sun, J.; Gu, A.; Jin, M.; Shen, Z.; Qiu, Z.; Wang, J.; Wang, X.; Zhan, Z.; et al. Expression of the coxsackie and adenovirus receptor in human lung cancers. Tumour Biol. 2013, 34, 17-24. [CrossRef]

26. Martin, T.A.; Watkins, G.; Jiang, W.G. The Coxsackie-adenovirus receptor has elevated expression in human breast cancer. Clin. Exp. Med. 2005, 5, 122-128. [CrossRef] [PubMed]

27. Reimer, D.; Steppan, I.; Wiedemair, A.; Concin, N.; Hofstetter, G.; Marth, C.; Muller-Holzner, E.; Zeimet, A.G. Soluble isoforms but not the transmembrane form of coxsackie-adenovirus receptor are of clinical relevance in epithelial ovarian cancer. Int. $J$. Cancer 2007, 120, 2568-2575. [CrossRef] [PubMed]

28. Giaginis, C.T.; Zarros, A.C.; Papaefthymiou, M.A.; Papadopouli, A.E.; Sfiniadakis, I.K.; Theocharis, S.E. Coxsackievirus and adenovirus receptor expression in human endometrial adenocarcinoma: Possible clinical implications. World J. Surg. Oncol. 2008, 6, 59. [CrossRef] [PubMed]

29. Dietel, M.; Hafner, N.; Jansen, L.; Durst, M.; Runnebaum, I.B. Novel splice variant CAR 4/6 of the coxsackie adenovirus receptor is differentially expressed in cervical carcinogenesis. J. Mol. Med. 2011, 89, 621-630. [CrossRef]

30. Wang, Y.; Wang, S.; Bao, Y.; Ni, C.; Guan, N.; Zhao, J.; Salford, L.G.; Widegren, B.; Fan, X. Coxsackievirus and adenovirus receptor expression in non-malignant lung tissues and clinical lung cancers. J. Mol. Histol. 2006, 37, 153-160. [CrossRef]

31. Morton, P.E.; Hicks, A.; Nastos, T.; Santis, G.; Parsons, M. CAR regulates epithelial cell junction stability through control of E-cadherin trafficking. Sci. Rep. 2013, 3, 2889. [CrossRef]

32. Coyne, C.B.; Bergelson, J.M. CAR: A virus receptor within the tight junction. Adv. Drug Deliv. Rev. 2005, 57, 869-882. [CrossRef]

33. Cohen, C.J.; Shieh, J.T.; Pickles, R.J.; Okegawa, T.; Hsieh, J.T.; Bergelson, J.M. The coxsackievirus and adenovirus receptor is a transmembrane component of the tight junction. Proc. Natl. Acad. Sci. USA 2001, 98, 15191-15196. [CrossRef] [PubMed]

34. Excoffon, K. The coxsackievirus and adenovirus receptor: Virological and biological beauty. FEBS Lett. 2020, 594, 1828-1837. [CrossRef] [PubMed]

35. Readler, J.M.; AlKahlout, A.S.; Kolawole, A.O.; Excoffon, K. Production of isoform-specific knockdown/knockout Madin-Darby canine kidney epithelial cells using CRISPR/Cas9. MethodsX 2020, 7, 101149. [CrossRef] [PubMed]

36. Readler, J.M.; AlKahlout, A.S.; Sharma, P.; Excoffon, K. Isoform specific editing of the coxsackievirus and adenovirus receptor. Virology 2019, 536, 20-26. [CrossRef] 
37. Dukes, J.D.; Whitley, P.; Chalmers, A.D. The MDCK variety pack: Choosing the right strain. BMC Cell Biol. 2011, 12, 43. [CrossRef]

38. Cohen, C.J.; Gaetz, J.; Ohman, T.; Bergelson, J.M. Multiple regions within the coxsackievirus and adenovirus receptor cytoplasmic domain are required for basolateral sorting. J. Biol. Chem. 2001, 276, 25392-25398. [CrossRef]

39. Sharma, P.; Martis, P.C.; Excoffon, K. Adenovirus transduction: More complicated than receptor expression. Virology 2017, 502, 144-151. [CrossRef]

40. Swiatecka-Urban, A.; Brown, A.; Moreau-Marquis, S.; Renuka, J.; Coutermarsh, B.; Barnaby, R.; Karlson, K.H.; Flotte, T.R.; Fukuda, M.; Langford, G.M.; et al. The short apical membrane half-life of rescued \{Delta\}F508-cystic fibrosis transmembrane conductance regulator (CFTR) results from accelerated endocytosis of \{Delta\}F508-CFTR in polarized human airway epithelial cells. J. Biol. Chem. 2005, 280, 36762-36772. [CrossRef]

41. Lie, P.P.; Cheng, C.Y.; Mruk, D.D. Crosstalk between desmoglein-2/desmocollin-2/Src kinase and coxsackie and adenovirus receptor /ZO-1 protein complexes, regulates blood-testis barrier dynamics. Int. J. Biochem. Cell Biol. 2010, 42, 975-986. [CrossRef]

42. Schwanhausser, B.; Busse, D.; Li, N.; Dittmar, G.; Schuchhardt, J.; Wolf, J.; Chen, W.; Selbach, M. Global quantification of mammalian gene expression control. Nature 2011, 473, 337-342. [CrossRef]

43. Hanwell, D.; Ishikawa, T.; Saleki, R.; Rotin, D. Trafficking and cell surface stability of the epithelial Na+ channel expressed in epithelial Madin-Darby canine kidney cells. J. Biol. Chem. 2002, 277, 9772-9779. [CrossRef] [PubMed]

44. Swiatecka-Urban, A.; Duhaime, M.; Coutermarsh, B.; Karlson, K.H.; Collawn, J.; Milewski, M.; Cutting, G.R.; Guggino, W.B.; Langford, G.; Stanton, B.A. PDZ domain interaction controls the endocytic recycling of the cystic fibrosis transmembrane conductance regulator. J. Biol. Chem. 2002, 277, 40099-40105. [CrossRef] [PubMed]

45. Chu, F.F.; Doyle, D. Turnover of plasma membrane proteins in rat hepatoma cells and primary cultures of rat hepatocytes. J. Biol. Chem. 1985, 260, 3097-3107. [CrossRef]

46. Hare, J.F.; Taylor, K. Mechanisms of plasma membrane protein degradation: Recycling proteins are degraded more rapidly than those confined to the cell surface. Proc. Natl. Acad. Sci. USA 1991, 88, 5902-5906. [CrossRef]

47. Excoffon, K.J.; Hruska-Hageman, A.; Klotz, M.; Traver, G.L.; Zabner, J. A role for the PDZ-binding domain of the coxsackie B virus and adenovirus receptor (CAR) in cell adhesion and growth. J. Cell Sci. 2004, 117, 4401-4409. [CrossRef] 